\title{
Lectins of Marine Hydrobionts
}

\author{
O. V. Chernikov ${ }^{1 *}$, V. I. Molchanova ${ }^{1}$, I. V. Chikalovets ${ }^{1}$, \\ A. S. Kondrashina ${ }^{1}$, W. Li ${ }^{2}$, and P. A. Lukyanov ${ }^{1}$ \\ ${ }^{1}$ Elyakov Pacific Institute of Bioorganic Chemistry, Far Eastern Branch of the Russian Academy of Sciences, \\ pr. 100 let Vladivostoku 159, 690022 Vladivostok, Russia; fax: +7 (423) 231-4050; E-mail: chernikov@piboc.dvo.ru \\ ${ }^{2}$ Dalian Ocean University, Heishijiao str. 52, 116023 Dalian, P. R. China; \\ fax: +86 (0411) 847-63-508; E-mail: aisingioro@hotmail.com
}

Received February 16, 2013

Revision received February 26, 2013

\begin{abstract}
Data from the literature and results of our research on lectins isolated from some kinds of marine hydrobionts such as clams, ascidians, sea worms, sponges, and algae are presented in this review. Results of comparative analysis of the basic physicochemical properties and biological activity of lectins isolated from various sources are discussed.
\end{abstract}

DOI: $10.1134 / \mathrm{S} 0006297913070080$

Key words: lectins, marine invertebrates, marine algae

In the modern view, proteins specifically recognizing and reversibly binding to certain carbohydrate glycoconjugate structures without change in covalent structure of the recognized glycosyl ligands are considered to be lectins. This definition most adequately accounts for the properties and characteristics of this group of proteins that are known in modern glycobiology. Lectins can be isolated from nearly all types of living organisms from viruses to humans, although those of higher plants still form the most numerous group of lectins. Lectins represent a large heterogeneous class of molecules with different properties and varying physiological functions [1].

There are many kinds of classifications that combine proteins with significantly different structures depending on carbohydrate specificity, source, molecular structure, or amino acid sequence. Galectins, C-, P-, or I-type lectins and pentraxins are the best-studied classes of lectins of higher animals [2].

Several immunological reactions, such as agglutination of cells (including erythrocytes) and precipitation of glycoproteins and polysaccharides, are typical of lectins. Some lectins cause selective agglutination of malignant tumor cells; this indicates that tumor and normal cells have different surface structure. Lectins are accepted as the most informative molecular probes allowing identification of glycoconjugates of cells and tissues and study of their dynamics under physiological and pathological conditions [3, 4].

* To whom correspondence should be addressed.
Being incorporated in the structure of tissues of animals, plants, and bacteria, lectins participate in regulation of their metabolism as well as in protection from some environmental agents. However, when isolated from living objects, lectins can be the valuable biochemical reagents used in experimental cytochemistry, diagnostics of some diseases, and in biotechnological processes of isolation of complex carbohydrate-containing substances [5]. In recent years there have been attempts to use lectins as drugs. These facts dictate the study of lectins by researchers working in various branches of biology, first and foremost in biochemistry, cytology, microbiology, plant physiology, biotechnology, and pharmacology. In spite of the fact that the first lectin was isolated more than a hundred years ago, intensive study of lectins began only in the last 30 years.

Marine organisms are relatively new sources of lectins. However, studies of the physiological role of these compounds as well as works with the use of endogenous and exogenous lectins in various living systems are now rather active. Lectins of marine invertebrates are of particular interest. They have been found in more than 300 species, and their carbohydrate specificity and molecular structures are defined.

Lectins of annelid worms and sponges, the most primitive representatives of this group, have molecular mass not more than $40 \mathrm{kDa}$ and usually are monomeric or dimeric proteins [6, 7]. As taxonometric or anatomic complexity of marine invertebrates rises, heterogeneity of lectins also rises: complex multimeric forms are organized 
in quaternary structures. Even lectins of shellfish and echinoderms demonstrate wide heterogeneity, being multimeric as well as monomeric and dimeric proteins. Lectins of arthropods - organisms with active modus vivendi, are multimers with molecular mass $450 \mathrm{kDa}$ and higher. Comparative analysis of plant lectins demonstrates an analogous tendency: unlike lectins of terrestrial plants, which have subunit structure and specificity to mono- and oligosaccharides, lectins of an older group of plants - marine algae, have the lower molecular masses, are usually monomeric, and do not exhibit affinity to monosaccharide residues. It is interesting that analogously to lectins of higher plants and vertebrates, lectins of invertebrates have higher affinity to $\beta$-anomeric forms of carbohydrates than to $\alpha$-anomeric forms [5].

As the organization level of the corresponding taxon of animals rises, the level of lectins changes from constitutive to facultative, which is more advantageous in the physiological sense, and the ability for secretion of lectins in hemolymph is achieved. Thus, most lectins isolated from sponges are components of their cell membranes; this is related with the absence of structured inner medium in the organism and distinct tissue differentiation [8]. In more complex organisms lectins are also either components of cell membranes or are synthesized and then secreted by cells of coelomic or hemal fluids (coelomic invertebrates), and also by other organs and tissues [9].

In spite of the fact that some lectins of invertebrates are essentially homologous to lectins isolated from vertebrates, by now such an important class of proteins cannot be completely classified in families because for most the amino acid sequence is not yet established [9]. Usually there are attempts to classify them as lectins of higher animals. Ogawa and coworkers suggest classification of lectins of marine invertebrates into $\mathrm{Ca}^{2+}$-dependent lectins (C-lectins), F-type lectins, and rhamnose-binding lectins (RBL) [10].

Thus, a number of isolated lectins of sea hydrobionts belong to the C-lectin family, but in contrast to many of the C-type lectins of vertebrates having several different functional domains, most of the C-type lectins of invertebrates include only the carbohydrate-recognizing domain (CRD) [3, 5, 8, 11-13]. Dependence of activity on the presence of $\mathrm{Ca}^{2+}$ is the main feature of lectins of this type [14]. Lectins belonging to the galectins, a family of evolutionally conservative lectins having affinity to $\beta$-galactosides and widespread in mammals, have been isolated from marine invertebrates in recent years $[15,16]$. The number of lectins with established primary and threedimensional structures has rapidly increased in the past few years. It is interesting that similarity in the tertiary structures of lectins isolated from various organisms was noted in spite of the absence of any homology in their amino acid sequences [17].

So, lectins isolated from marine hydrobionts belong to the significantly different class of proteins not only from the viewpoint of structure, but also of functional aspects including their unique carbohydrate specificity.

The literature data and results of our research on lectins isolated from some kinds of marine hydrobionts, such as clams, ascidians, worms, sponges, and algae are presented in this review because in recent years the authors have been isolated lectins from these sources and studied their structures and functions.

\section{LECTINS OF CLAMS}

Phylum Mollusca is one of the most numerous and important groups of the animal realm: there are more than 200,000 species found in terrestrial, freshwater, and marine environments [18]. Study of lectins from mollusks is of significant interest because of data on their antitumor, antiviral, and antimicrobial activity [19-21]. However, among lectins of Mollusca phylum, those isolated from species having economic or medical value such as mussels or oysters are of maximal interest [22]. Most lectins that are either associated or not associated with cell membrane of hemocytes and often perform protective function in animals have been isolated from hemolymph of clams [23, 24]. Lectins have also been detected in plasma and various organs and tissues: digestive gland, gonads, and soft tissues. Lectins from plasma are usually multimeric protein complexes with several sites for binding to ligands [25]. Lectins of clams are specific to various carbohydrates. Specificity to Gal, GalNAc, Glc, Lac, Fuc, and also to sialic acids and glycoproteins of mucin type is typical of lectins of these marine invertebrates. Such wide range of specificities of lectins of the Bivalvia family can be due to the presence of multiple isoforms of lectins specific for a particular monosaccharide or a group of monosaccharides with similar structures. For example, a heterogeneous sialospecific lectin composed of three isolectins has been found in hemolymph of the mussel Modiolus modiolus. Two of these lectins, modiolin $\mathrm{H}$ and modiolin $\mathrm{E}$, agglutinate human and horse erythrocytes, respectively, but only for modiolin $\mathrm{E} \mathrm{Ca}^{2+}$ is required for manifestation of activity [26]. Different subunits seem to be capable of binding to several monosaccharides with different affinity. Such organization can extend the range of ligands bound by them. Moreover, lectins of clams consisting of identical subunits are able to react with various monosaccharides. Lectin of the oyster Pinctada fucata is an example; with maximal efficiency it binds to Gal, and it also exhibits specificity to other carbohydrates (Glc, Man, Fuc, GalN, GalNAc, ManNAc, NeuNAc) and agglutinates various kinds of erythrocytes [27]. Lectins isolated from the clams Tegillarca granosa and Ostrea chilensis also demonstrate multispecificity [28, 29].

Most lectins isolated from clams are of C-type. Most often lectins of this type, e.g. those isolated from the 
clams Tridacna maxima, T. derasa, T. crocea, T. gigas, Crassostrea virginica, Pinctada fucata martensii, and Tegillarca granosa are high molecular weight multisubunit proteins with molecular masses in the range $123-500 \mathrm{kDa}$ [27, 28, 30-32]. Experimental data indicate that the specificity to Gal and GalNAc as well as ability for agglutination of erythrocytes of various types is typical of the C-type lectins of clams [33].

However, low molecular weight lectins also occur among the $\mathrm{C}$-type lectins. For example, a $\mathrm{Ca}^{2+}$-dependent lectin (chilectin) with molecular mass $12 \mathrm{kDa}$ has been isolated from hemolymph of the oyster Ostrea chilensis [29]. Analysis of the primary structure of codakin, a lectin from the clam Codakia orbicularis (molecular mass $14 \mathrm{kDa}$ ), showed partial homology with various $\mathrm{C}$-type lectins of higher animals. The amino acid sequence of codakin contains a tripeptide fragment EPN (Glu-Pro-Asn) often found in Man-binding lectins [34].

A wide range of the tested cells bound by plasma lectins of clams can be due not only to polyreactivity of their lectins, but also by the simultaneous presence of several lectins specific to different sugars in plasma. Two lectins, gigalin $\mathrm{E}$ and gigalin $\mathrm{H}$, agglutinating horse and human erythrocytes, respectively, have been found in plasma of the oyster Crassostrea gigas [35]. Later the complete amino acid sequences of three lectins, namely the C-type lectin (CgCLec-1), galectin (CgGal), and fucolectin were obtained for this mollusk by molecular biological methods [36]. Several lectins have been isolated from the Manila clam Ruditapes philippinarum and characterized; all of them belong to C-type and are high molecular weight proteins in the native state. Lectin MCL exhibits unusual specificity to GalNAc residues, porcine stomach mucin (PSM), and highly branched mannans [37] or to Gal terminal residues [38]. Activity of MCL3 can be inhibited by GalNAc, Man, Lac, and raffinose and also by bovine submaxillary glands mucin (BSM) and branched mannan [39]. GalNAc and PSM are the best inhibitors of MCL4 activity, and Fuc and NeuAc neutralize agglutination of erythrocytes by lectin to a lesser extent [40]. Lectin MCsialec appears to be specific to sialic acids [41]. Two lectins (Gal-specific Anadarin P [42] and heparin-specific Anadarin MS) have been isolated from plasma of the mollusk Anadara granosa; in contrast to other heparin-binding lectins, Anadarin MS exhibits unique specificity to glycosaminoglycans containing iduronic acid [43]. Lectin AFL, which appears to be specific only to $\mathrm{N}$-glycolylneuraminic acid and does not interact with $\mathrm{N}$-acetylneuraminic acid, has also been isolated from muscle of this mollusk [43].

Studies of the family of rhamnose-binding lectins (RBL) have been performed in recent years. Although RBL are essentially similar to galectins in specificity to galactosides and have $\mathrm{Ca}^{2+}$-independence, they differ from galectins in CRD structure [44]. RBL participate in various biological processes such as fertilization, cell proliferation, etc. Most RBL have been isolated from fish eggs [44, 45], although lectin isolated from the clam Pteria penguin have been also described: its amino acid sequence appeared to be homologous to those of the known RBL in spite of the fact that rhamnose only negligibly inhibited the hemagglutination reaction [46].

By now a significant number of lectins that cannot be assigned to any of the known classes described for lectins of higher animals have been isolated from clams. They are mainly metal-independent lectins with molecular masses in the range $14-40 \mathrm{kDa}$, and they vary widely in specificity both to monosaccharides and glycoproteins [46-48].

Lectins from clams of the Mytilidae family have been widely studied. Specificity to monosaccharides Gal and GalNAc is typical of these lectins; many of them have molecular mass about $18 \mathrm{kDa}$ [47-50]. We isolated a $\mathrm{Ca}^{2+}$-independent $\mathrm{Gal} / \mathrm{GalNAc}$-specific lectin (CGL) with molecular mass $18 \mathrm{kDa}$ from the mussel Crenomytilus grayanus and studied its physicochemical characteristics and biological activity [49]. Inhibition by glycoprotein shows that CGL possesses a very high affinity to mucin-type glycoproteins, which are characterized by high content of the $\mathrm{O}$-glycoside-bound chains and their dense location on the protein core. Many cell receptors are known to be glycoproteins of the mucin-type. In accord with this, we have shown that peroxidase-labeled CGL is an excellent histochemical marker. CGL reveals difference in composition of the mucin-type glycoproteins, both secreted and bound to cell surface, in the normal state and in highly differentiated adenocarcinomas. CGL can be used in histological studies as an instrument to mark cells of certain type and to follow glycoconjugatedependent processes in normal tissues and in tumors with participation of mucin-type glycoproteins [51].

The search for homologs in the known databases revealed that the CGL polypeptide sequence obtained by us has significant structural homology with the Gal/GalNAc-specific lectin MytiLec from the mussel Mytilus galloprovincialis [48]. However, these lectins are not similar to any other known proteins. This indicates that CGL and MytiLec form a completely new class of Gal-specific lectins of marine invertebrates. We screened among clams belonging to the same Mytilidae family. Hemagglutinins were found in mantle extract from the mussel Mytilus trossulus [52]; as a result, Gal/GalNAcspecific lectin (MTL) similar to CGL in physicochemical properties was isolated from this mussel. Using antibodies against CGL, we revealed $50 \%$ cross-reactivity between these lectins, and this is in accord with data on high homology of the lectins isolated from closely related species [50].

Lectins of the mussel Mytilus edulis have been widely studied. The presence of lectin activity that can be inhibited by NeuNAc, BSM, and fetuin in mussel hemolymph was first shown by Hardy et al. in 1976 [53]. 
Later Gal-specific lectins were isolated from hemolymph [54] and tissue homogenate of this mollusk [47]. Three proteins, M3, M6, and M7, with amino acid sequence homologous to that of the C-type lectins and exhibiting affinity to asialofetuin were isolated from $M$. edulis sperm [55]. The amino acid sequence of the secretory lectin MeML was determined by molecular biological methods; this lectin is expressed by mucocytes embedding epithelium of the mantle complex of organs and intestine and has not been detected in other tissues including hemocytes [56]. It is interesting to note that although lectins of $M$. edulis have been isolated from various organs and tissues and differ in specificity, in all cases $\mathrm{Ca}^{2+}$ is required for their activity. A new multigenic family of proteins containing a fibrinogen-like domain was recently discovered in clams belonging to the Mytilus genus [57]. Two such lectins, named MytFREP1 and MytFREP2, were cloned from hemocytes of M. edulis.

It should be noted that in recent years a tendency for determination of the primary structure of new lectins without their isolation in the native state has appeared. Works in this direction by Chinese investigators have been especially fruitful: they not only have determined the structures of new lectins, but also revealed their functional roles in mollusks. For example, recombinant lectin rAiCTL5 obtained after cloning of a new lectin from the scallop Argopecten irradians agglutinates gram-negative bacteria, interacting with lipopolysaccharides (LPS) [58]. The F-type lectin (PmF-lectin) has been cloned from the oyster Pinctada martensii. RT-PCR and qRT-PCR analysis has revealed a significantly increased level of expression of mRNA lectin as a response to invasion by the pathogenic bacterium Vibrio alginolyticus; this indicates that PmF-lectin participates in protective reactions of the animal [59].

The number of lectins whose specificity has been studied in detail and for which endogenous ligands are known still remains very small, and this fact hinders understanding of their biological functions [33].

\section{LECTINS OF ASCIDIANS}

Hemagglutinating activity has been discovered in hemolymph of many ascidians, which are considered as a key group in phylogenesis of chordates [60, 61]. Hemocytes are responsible for synthesis of lectins of hemolymph or at least are the main place of their synthesis, since lectins initially have been membrane receptors of hemocytes [62]. A large number of lectins binding to a wide variety of carbohydrates including $\alpha 1-6 \mathrm{Gal}, \beta 1-$ 4Gal, GalNAc, GlcNAc, ManN, Fuc, lactose, melibiose, raffinose, mannans, sialoconjugates, and bacterial LPS have been isolated from ascidians [63, 64]. Many researchers rationalize the wide variety of ligand specificities of lectins of hemolymph by the fact that lectins of ascidians have protective function in the animals, and for manifestation of this function molecular forms (structural classes and isoforms) should be variable [64]. Protective function also results in a wide variety in molecular masses of lectins of ascidians. High molecular weight lectins with masses $90-600 \mathrm{kDa}$ in the native state have been isolated from the ascidians Clavelina picta, Styela plicata, Botrylloides leachii, and Halocynthia roretzi [64-69]. Low molecular weight lectins with masses $14-63 \mathrm{kDa}$ have been isolated from H. pyriformis, C. picta, Didemnum candidum, D. ternatanum, Polyandrocarpa misakiensis, Botryllus schlosseri, S. plicata, and Ascidia malaca [64, 6973]. Both high and low molecular mass lectins are mainly subunit proteins $[65-69,73]$, although monomers are also described $[64,65,71,73]$. Most of the lectins are $\mathrm{Ca}^{2+}$-dependent [65-68, 71, 72]. The presence of several lectins with overlapping carbohydrate specificity is a characteristic feature of some species of ascidians $[64,67$, $69,70]$.

In spite of the lack of structural information that would allow assignment of lectins of ascidians to one of the known classes, some demonstrate significant structural homology with lectins isolated from vertebrates. For example, a number of the natural or inducible galectins have been found in plasma or on the surface of hemocytes [64, 66]. Gal-binding humoral opsonin with the properties of galectin has been found in the supernatant of lysate of hemocytes from the colonial ascidian $B$. schlosseri [72], and humoral opsonin of C-type has been isolated from hemolymph of the ascidian Styela clava [74]. Cytoplasmic lectins, $\mathrm{Ca}^{2+}$-independent and $\beta$ galactoside-specific, with properties typical of galectins, have been isolated from the ascidian Ciona intestinalis [75].

Several lectins that can be ascribed to the class of collectins or ficollectins playing an important role in the innate immunity of the organism have been isolated from ascidians [76]. Collectins or ficollectins have similar structures containing collagen-like and carbohydratebinding domains. In the case of collectins, the CRD is specific for Glc/Man or Gal derivatives, and ficollins have a fibrinogen-like domain at the $\mathrm{C}$-end; this domain can interact with various carbohydrates, most often with GlcNAc. Thus, two Gal-specific metal-dependent lectins with molecular masses 43 and $90 \mathrm{kDa}$ have been isolated from the ascidian $S$. plicata and characterized. Determination of amino acid content and amino acid sequence shows that these lectins are similar to collectins of higher animals [65]. Similar lectins have been isolated also from other ascidians. The ascidian $H$. roretzi closely related to $S$. plicata has four ficollin-like genes encoding fibrinogen-like domains and a collagen-like sequence [77]. A number of genes similar to genes of ficollins and collectins have been found in the genome of the ascidian $C$. intestinalis [78]. Recently, a new member of the RBL family was isolated from the colonial ascidian $B$. schlosseri 
and characterized. This lectin is shown to play an important role in immunity of the ascidian [79].

Two Gal-specific lectins, DCL-I and DCL-II, were isolated from plasma of the ascidian Didemnum candidum, and their physicochemical properties, amino acid content, and the $\mathrm{N}$-terminal amino acid sequence were studied [80]. Both lectins have subunit structure, similar molecular mass, $\mathrm{pH}$ optimum, and thermal stability and are metal-independent proteins. However, it appears that in spite of the similar physicochemical characteristics, these lectins differ in amino acid content and have serologic difference. It was also shown that DCL-I exhibits mitogenic activity towards mouse thymocytes and splenocytes [81].

We have also isolated two lectins from the colonial ascidian Didemnum ternatanum: a GlcNAc-specific lectin (DTL) [69] and a GlcNAc/GalNAc-specific lectin (DTL-A) [70]. Both are $\mathrm{Ca}^{2+}$-independent, have rather low molecular mass (9 and $14 \mathrm{kDa}$, respectively), but DTL in the native state exists as a trimeric structure, while DTL-A forms high molecular weight aggregates. Beside this, DTL and DTL-A have different N-terminal amino acid sequences and differ in binding to erythrocytes. DTL-A agglutinates both trypsinized and nontrypsinized erythrocytes, while DTL only trypsinized ones. In contrast to all other known GlcNAc-specific lectins, DTL has a less extended carbohydrate-binding site. The hydroxyl groups at C-3 and C-4 and also the acetamide group of GlcNAc participate in binding. Similar results were obtained for DCL-I from the ascidian D. candidum. This lectin also has a small CRD that interacts only with the hydroxyl groups at C-2, C-3, and C-4 of Gal residues. In contrast to DTL, DTL-A binds not only to GlcNAc, but also to GalNAc, BSM, asialoBSM, heparin, and dextran sulfate. DTL-A binding to structurally different ligands suggests multispecificity of this lectin. The data on inhibition of DTL-A binding to BSM and heparin indicate that this lectin probably contains two independent sites: GlcNAc/GalNAc-binding site and an additional one responsible for interaction with heparin and dextran sulfate. A number of heparin-binding lectins have been isolated from higher animals, including humans, whereas only several such lectins have been found in marine invertebrates [82, 83], and only one similar lectin has been isolated from ascidians [83]. In contrast to DTL-A, this lectin has only one binding site for heparin, chondroitin sulfate, and LPS.

We found that DTL has an effect on growth, DNA and RNA synthesis, and morphology of HeLa tumor cells. Lectin also appears to be active towards embryonal cells of marine invertebrates. As found experimentally, DTL acts as an adhesive and growth factor on cultivated cells of sea urchin and mussel at a particular phase of their development. DTL significantly increases the lifetime of cells and can be useful in production of cell culture of echinoderms and mollusks [84, 85].

\section{LECTINS OF SEA WORMS}

Only limited data on lectins of sea worms is now available as compared to the data on lectins of other sea invertebrates. Isolation, physicochemical properties, and in some cases biological activity and primary structure of such lectins have been described. Amphitritin, a $\mathrm{Ca}^{2+}$ independent GlcNAc-specific lectin with molecular mass $30 \mathrm{kDa}$ was the first hemagglutinin isolated from a sea worm Amphitrite ornata [86].

Later a number of lectins recognizing Gal, GalNAc, and GlcNAc were isolated from other sea worms (polychaetes, echiurids, sipunculids) [6, 87-95] and characterized. All these lectins agglutinate human erythrocytes and in some cases also rat, sheep, and rabbit erythrocytes, the maximal activity being exhibited against the latter. Treatment of erythrocytes by trypsin resulted in their enhanced agglutination by lectins [6, 89, 91-95]. Most lectins are active in the $\mathrm{pH}$ range $6.0-9.0$, and the presence of bivalent metal cations is not required [6, 86-89, 91], although metal-dependent lectins are also found, e.g. a thermally stable lectin from the coelomic liquid of Sipunculus nudus [95]. Molecular masses of the isolated lectins vary within the range $12-36 \mathrm{kDa}$, some of the lectins are monomers [89, 92, 93], and in several cases they appear to be dimeric or even tetrameric proteins; this suggests the presence of disulfide bonds between cysteine residues in the lectin molecule $[6,91,95]$. The destruction of oligomeric structure by addition of $\beta$-mercaptoethanol can result in complete loss of hemagglutinating activity, as shown for the lectin from the coelomic liquid of $S$. nudus [95]. Most of isolated lectins are glycoproteins; carbohydrate content varies within the range 2$13 \%$, and the amino acid composition is characterized by increased content of acidic amino acids [86, 91].

Hemagglutinating activity of lectins is inhibited by simple sugars: Gal, GalNAc, GlcNAc and their derivatives, Gal-containing oligosaccharides (lactose, melibiose), and in some cases by glycoproteins: mucin, fetuin, and their desialized derivatives $[89,92,93,95]$ and also by $\mathrm{N}$-glycans [91, 92]. The effect of the various substituents and also their steric position in hapten molecules has been studied; introduction of para-nitrophenyl aglycon and also the methyl group at $\mathrm{C}-1$ in $\alpha$ - and $\beta$-positions can result in decrease as well as increase in the inhibiting properties of a ligand. Thus, lectin from coelomic liquid of $S$. nudus demonstrates significant specificity to $\alpha$ anomers (Me- $\alpha-\mathrm{D}-\mathrm{Gal} p$ ) [95], while others, e.g. lectins from Chaetopterus variopedatus [89], the echiroid worm Urechis unicinctus, and two annelid worms Neanthes japonica and Marphysa sanguine [88] - to $\beta$-anomers. Lectins from Perinereis nuntia [92] and Serpula vermicularis [91] demonstrate specificity to both $\alpha$ - and $\beta$ anomers of Gal and GlcNAc, respectively.

It is experimentally proved that some lectins of sea worms, e.g. U. unicinctus, N. japonica, M. sanguine, $P$. 
nuntia, are bound to endogenous ligands in the animal body, and that is why lectins are extracted in the presence of a hapten (Gal, Lac) [6, 88, 92].

A $\mathrm{Ca}^{2+}$-independent $\mathrm{Gal}$-specific lectin $(30 \mathrm{kDa})$ named CVL has been isolated from the sea worm Chaetopterus variopedatus and characterized in our laboratory. CVL exhibits specificity to $\beta$-D-Galp. It was also shown that mucin, fetuin, and their desialized derivatives are efficient inhibitors of hemagglutination. Desialization of fetuin is accompanied by a significant increase in its inhibiting activity, while the desialized mucin exhibits the same activity as the initial glycoprotein. The binding properties of the lectin do not depend on the presence of bivalent cations [89].

We isolated two new $\mathrm{Ca}^{2+}$-independent lectins, SVL1 and SVL-2, from the sea worm Serpula vermicularis [96]. Both these lectins are oligomers: two subunits are bound by disulfide bonds and organized in a tetramer. Such structural organization of lectins is rather rare, though similar tetrameric structures have been described for lectins from the tropical sponges Aplysina archeri and A. lawnosa [97]. It was shown that hemagglutinating activity of SVL-1 is inhibited by the branched mannans and glycoproteins with $\mathrm{O}$-bound carbohydrate chains such as mucins, while SVL-2 is a GlcNAc-specific lectin. As shown by solid-phase lectin-enzyme analysis, N-glycans with GlcNAc terminal residues - ovomucoid and ovalbumin - are efficient inhibitors among glycoproteins [91].

\section{LECTINS OF SPONGES}

Hemagglutinins in sponges were first found in 1968 [98]. Then lectins from various species of these invertebrates were isolated and rather well characterized from the following species: Aaptos papillata, Geodia cydonium, Axinella polypoides, Aplysina archeri and A. lawnosa, Aphrocallistes vastus, Haliclona cratera, Suberites domuncula, Halichondria panacea, H. okadai, Cinachyrella alloclada and Desmapsama anchorata [97, 99-110]. Most of these studies were done in Germany, Japan, and Brazil.

Studies of 48 species of sponges from various regions of the world's oceans have shown that lectins are constituents of $42 \%$ of sponge species. Isolated and characterized lectins of sponges usually are low molecular weight proteins, agglutinate human erythrocytes of $\mathrm{ABO}$ groups, and exhibit specificity to Gal, Lac, and GalNAc [7]. Some species contain several lectins with different $[99,106]$ or equal specificity [100]; in the latter case they differ in amino acid composition and isoelectric point. There are fewer lectins exhibiting specificity to other monosaccharides and glycoproteins. Three lectins (I, II, and III) with different molecular mass, isoelectric point, amino acid composition, and carbohydrate specificity have been isolated from the sponge $A$. papillata. Lectins II and III have maximal affinity to GalNAc, but their activity is also inhibited by GlcNAc and sialic acid. Lectin I has maximal affinity to ligands containing terminal GlcNAc residues [99]. Hemagglutination caused by a lectin from the sponge $H$. panacea is inhibited by fetuin, GalA, GlcA, and Fuc [106]. Mucin-binding lectin CAL inhibiting growth of $E$. coli $\mathrm{K} 1$ has been isolated from the sponge Craniella australiensis [110, 111].

For most lectins of sponges, the presence of metal cations is not required for exhibiting activity. Clustering of sequences of lectins from various species with subsequent comparison in pairs has shown that lectins of sponges could be precursors of the S-type lectins of vertebrates [100].

\section{LECTINS OF RED ALGAE}

Among marine hydrobionts, algae along with marine invertebrates attract attention of researchers as potential sources of lectins. Accessibility of algae and their possible cultivation in large volumes is accompanied by complexity of their protein isolation caused by the presence of pigments in large amounts; that is why a few lectins have been isolated from marine plants as compared with terrestrial ones, and only a few lectins have been completely characterized.

The presence of lectins in 24 algae species from the seacoast of Puerto Rico was first reported by Boyd in 1966 [112]. Most lectins have been isolated from red algae such as Cystoclonium purpureum, Palmaria palmata, Eucheuma serra, Enantiocladia duperreyi, Amansia multifida, Gracilaria verrucosa, G. ornata, G. cornea, and Hypnea cervicornis [113-117].

Algal lectins differ from plant lectins in certain properties. Lectins of red algae mainly have low molecular masses, and their isoelectric points are within the range 4.0-6.0. Most of them, e.g. lectins from the red algae Carpopeltis flabellata, Solieria robusta, Bryothamnion seaforthii, B. triquetrum, Pterocladiella capillacea, $G$. ornata, and $G$. cornea are monomeric proteins with high content of acidic amino acids and do not require the presence of bivalent cations for exhibiting their biological activity. These lectins do not bind to monosaccharides, and their activity is inhibited by complex oligosaccharides and/or glycoproteins [116, 118-121].

However, it is known that some lectins from red algae are tetramers (G. verrucosa [122]), trimers (Ptilota filicina, P. serrata, and P. gunneri [123]) or dimers (Palmaria palmata and Vidalia obtusiloba [124, 125]). Their hemagglutinating activity can be metal-dependent and inhibited by simple sugars and in some cases by glycoproteins. A lectin from $P$. gunneri is not inhibited by glycoproteins [123].

We have isolated lectin TCL from the red alga Tichocarpus crinitus; this is a monomeric metal-inde- 
pendent glycoprotein [126]. TCL activity is inhibited by glycoproteins mucin and fetuin, but it is not inhibited by simple monosaccharides. Specificity, molecular organization, and physical and chemical properties such as thermal stability, $\mathrm{pH}$ dependence, and $\mathrm{p} I$ of TCL are similar to those of other lectins from red algae, e.g. Carpopeltis flabellate, S. robusta, G. bursa-pastoris, G. ornata, and G. cornea [116-118, 120, 121].

In spite of the progress attained in biochemical characterization of lectins from marine algae, additional information is required for further understanding of their properties, structure, and biological functions.

\section{BIOLOGICAL ACTIVITY}

Functions of lectins in nature are variable and based on their ability to recognize and bind carbohydrate fragments of glycoconjugates either in solution or on a cell surface. Lectins are involved in various physiological processes, functioning as cell-surface receptors [127], participating in intercellular interactions in the course of cell development and differentiation [2], and fulfilling a protective function as participants of the innate immunity [17]. Interactions between humoral factors, hemocytes, and target cells resulting in phagocytosis and encapsulation of xenomaterial play a key role in recognition of nonself tissues and cells. The agglutinizing and opsonizing plasma factors are most often lectins [75]. Lectins in plasma of clams are major proteins, that is, their relative concentration is rather high. They selectively agglutinate gram-positive and gram-negative microorganisms associated with marine invertebrates in nature. Agglutination allows immobilization of a pathogen and prevents its spread and penetration into other tissues. Binding and phagocytosis of a microorganism by a hemocyte is defined by the presence of carbohydrate structures on the bacterial surface and lectins on the hemocyte surface.

Acting as opsonins, humoral lectins can bind to the microorganism surface by one binding site and to the hemocyte surface by another binding site, thus forming a bridge between a phagocyte and a bacterium [128]. The role of specific lectins in the parasite-host system is noted. Certain lines of mollusks, producing large amounts of lectins that agglutinate sporecysts of parasites, appear to be resistant to infection. This fact suggests that lectins are bioregulators in systems of symbiosis of animal organism with microorganisms and parasites of invertebrates [13].

While studying antibacterial activity of lectins of marine hydrobionts in experiments in vitro, it has been shown that they can exhibit inhibitory as well stimulatory effects on growth of gram-positive and gram-negative bacteria. This depends on specificity of each lectin and its ability to bind to carbohydrate chains on the surface of the bacterial cell [40, 129-132].
In recent years, many papers on estimation of expression of lectin mRNA in response to bacterial invasion have been published. The lectins are supposed to be involved in recognition and removal of bacterial pathogens from the mollusk organism [58, 59].

We have studied the interaction of lectins CGL, DTL, DTL-A, and TCL with some representatives of gram-positive (Bacillus subtilis, Salinibacterium amurskyense, Staphylococcus aureus) and gram-negative (Arenibacter troitsensis, Chryseobacterium scophthalmum, Escherichia coli, Pseudomonas aeruginosa) bacteria and also fungi (Candida albicans). As shown by agglutination, solid-phase lectin-enzyme analysis, and turbidimetry, concentration-dependent binding is observed for all lectins. This binding is destroyed by specific inhibitors, and thus the carbohydrate-protein nature of the interaction is supported. This indicates the presence of carbohydrate structures specific to these lectins on the surface of bacteria [133].

Binding to specific carbohydrate receptors on a cell surface, lectins activate these receptors and thus initiate a signal cascade. If the cells are involved in the immunity system, binding to lectin can induce a specific cell response, including induction of secretion of cytokines. For certain lectins, cytokine-inducing activity has been shown in experiments with human and murine immunecompetent cells [134, 135].

As shown in experiments with human peripheral blood cells, lectins CGL, DTL, DTL-A, SVL-1, SVL-2, and TCL isolated by us enhance synthesis of anti-inflammatory cytokines such as TNF- $\alpha$, IL- 6 , and IFN- $\gamma$. Moreover, CGL and TCL decrease overexpression of TNF- $\alpha$ and IL- 6 on stimulation of cells by LPS, thus exhibiting immunomodulating properties [133]. MTL, a lectin from a mussel, also stimulates the induced and spontaneous production of anti-inflammatory cytokines TNF- $\alpha$ and IFN- $\gamma$. In a case of induction of cells by LPS, we observed some decrease in the level of anti-inflammatory cytokine IL-4, especially at low concentration of lectin; this indicates that lectin exhibits immunomodulating activity [50]. In the last six years several papers on cytokine-like molecules of invertebrates, comparative immunology, and evolution of cytokines have been published. In these papers the terms "putative cytokine", "cytokine-like", etc. have been used for the first time [136]. The data suggest that lectins are factors stimulating production of cytokine analogs in mollusks.

One more property of lectins has been used for many years while studying cell proliferation. Some lectins are mitogens, activating lymphocytes and inducing their division. It has been shown that such activity is first typical of phytolectins such as concanavalin A (Con A) and phytohemagglutinin. Some lectins therewith selectively affect only T- or B-lymphocytes, while others stimulate proliferation of both groups of lymphocytes. The produced effect depends on concentrations used, valence, and/or 
molecule dimensions [137]. Lectin often causes a cytotoxic effect on lymphocytes on increasing above the optimal concentration. Several new lectins exhibiting mitogenic activity have been isolated from marine hydrobionts during the last 20 years. This activity is mainly typical of lectins isolated from sponges [110, 138-140] and marine algae $[114,141]$.

As for lectins isolated in our laboratory, only TCL and SVL-1 stimulate growth of lymphocytes; however, they appeared to be significantly weaker activators than the well-known phytomitogen Con A [133]. It should be noted that for exhibiting mitogenic activity, significantly higher concentrations of lectins from marine hydrobionts are required than those of phytolectins.

Today much attention is given to lectins of marine hydrobionts, first of all algae, exhibiting anti-HIV activity. In contrast to the antiviral preparations used in medicine, aimed at suppression of the life cycle of HIV, lectins prevent penetration and further propagation of virus, binding to carbohydrate chains of glycoproteins of its envelope and blocking association of virion with receptor on cell membrane. In this case the highly mannose-containing $\mathrm{N}$-bound oligosaccharide chains act as ligands for the lectin [142-144]. A lectin exhibiting affinity to Glc, Man, and GlcNAc and a high anti-HIV activity was isolated from the red alga Griffithsia spp. in 2005 [145]. Further studies have demonstrated that this lectin, named griffithsin, is active against atypical pneumonia and other pathogenic coronaviruses [146], hepatitis C virus [147], and Japanese encephalitis virus [148]. This lectin does not exhibit mitogenic activity towards human mononuclear cells and does not affect production levels of the main cytokines [149, 150], so why further development of antiviral preparations based on griffithsin is perspective. Lectin KAA-2 exhibiting antiviral activity against a wide variety of influenza strains including swine influenza virus H1N1 has been isolated from another red alga, Kappaphycus alvarezii [151]. Lectin BCA isolated from the green alga Boodlea coacta is also active against influenza viruses of A and B types and HIV [152].

Lectins isolated by us also demonstrate antiviral activity. As shown by in vitro experiments, CGL (mussel), DTL and DTL-A (ascidian), and SLV-1 and SLV-2 (sea worm) lectins exhibit antiviral activity against HIV [96], this activity being increasing in the following series: CGL, DTL-A, SVL-2, DTL. Lectin CVL from a sea worm inhibits the cytopathic effect induced by HIV-1 [90]. Probably lectins block viral proteins gp 120 or gp 41 , which are glycoproteins with highly-mannose and hybrid types of carbohydrate chains, and thus hinder binding.

This work was financially supported by the Russian Foundation for Basic Research (grant Nos. 12-04-00862 and 12-04-31208/12) and the Program of Fundamental Studies of the Russian Academy of Sciences Presidium "Molecular and Cell Biology".

\section{REFERENCES}

1. Sharon, N. (2007) J. Biol. Chem., 282, 2753-2764.

2. Kilpatrick, C. D. (2002) Biochim. Biophys. Acta, 1572, 187197.

3. Lutsik, A. D., Detyuk, E. S., and Lutsik, M. D. (1989) Lectins in Histochemistry [in Russian], Vischa Shkola Publishers, L'vov.

4. Lehr, C. M., and Gabor, F. (2004) Adv. Drug. Deliv. Rev., 56, 419-420.

5. Loenko, Yu. N., Glazkova, V. E., Artyukhov, A. A., and Ovodova, R. G. (1992) Uspekhi Sovrem. Biol., 112, 785-794.

6. Matsui, T. (1984) Biol. Bull., 166, 178-188.

7. Mebs, D., Weilor, I., and Heinke, H. F. (1985) Toxicon, 23, 955-962.

8. Polevschikov, A. V. (1996) Zh. Obshch. Biol., 57, 718-739.

9. Vasta, G. R. (1992) in Glycoconjugates (Allen, H. J., and Kisailus, E. C., eds.) Marcel Dekker, N. Y., pp. 593-634.

10. Ogawa, T., Watanabe, M., Naganuma, T., and Muramoto, K. (2011) J. Amino Acids, 2011, Article ID 838914, doi:10.4061/2011/838914.

11. Arason, G. J. (1996) Fish Shellfish Immunol., 6, 277-289.

12. Lis, H., and Sharon, N. (1998) Chem. Rev., 98, 637-674.

13. Polevschikov, A. V. (1996) Immunologiya, 1, 48-56.

14. Lukyanov, P. A., Belogortseva, N. I., Bulgakov, A. A., Kurika, A. V., and Novikova, O. D. (1996) PICES Sci. Report, 6, 348-352.

15. Hirabayashi, J., Satoh, M., and Kasai, K. (1992) J. Biol. Chem., 267, 15485-15490.

16. Pfeifer, K., Haasemann, M., Gamulin, V., Bretting, H., Fahrenholz, F., and Muller, W. E. G. (1993) Glycobiology, 3, 179-184.

17. Sharon, N., and Lis, H. (2004) Glycobiology, 14, 53R-62R.

18. Ponder, W. F., and Lindberg, D. R. (2008) in Phylogeny and Evolution of the Mollusca (Ponder, W. F., and Lindberg, D. R., eds.) University of California Press, Berkeley, pp. 1-18.

19. Molchanova, V., Chikalovets, I., Chernikov, O., Belogortseva, N., Li, W., Wang, J. H., Yang, D-Y. O., Zheng, Y.-T., and Lukyanov, P. (2007) Comp. Biochem. Physiol. C, Toxicol. Pharmacol., 145, 184-193.

20. Smith, V. J., Desbois, A. P., and Dyrynda, E. A. (2010) Mar. Drugs, 8, 1213-1262.

21. Matsumoto, R., Fujii, Y., Kawsar, S. M. A., Kanaly, R. A., Yasumitsu, H., Koide, Y., Hasan, I., Iwahara, C., Ogawa, Y., Im, C. H., Sugawara, S., Hosono, M., Nitta, K., Hamako, J., Matsui, T., and Ozeki, Y. (2012) Toxins, 4, 323-338.

22. Yakovleva, N. V., Samojlevich, M. P., and Gorbushin, A. M. (2001) Zh. Evol. Biokhim. Fiziol., 37, 270-277.

23. Zhang, H., Wang, H., Wang, L. L., Song, X. Y., Zhao, J. M., Qiu, L. M., Li, L., Cong, M., and Song, L. S. (2009) Fish Shellfish Immunol., 26, 707-715.

24. Tasumi, S., and Vasta, G. R. (2007) J. Immunol., 179, 30863098.

25. Chu, F. E. (1988) Amer. Fish. Soc. Sp. Publ., 18, 178-188.

26. Tunkijjanukij, S., Mikkelsen, H. V., and Olafsen, J. A. (1997) Comp. Biochem. Phys. B, Biochem. Mol. Biol., 117, 273-286.

27. Suzuki, T., and Mori, K. (1989) Comp. Biochem. Physiol. B, 92, 455-462.

28. Chen, Y. S., Ke, J. Y., and Rao, X. Z. (2006) Fen. Zi. Xi. Bao. Sheng. Wu. Xue. Bao, 39, 453-461. 
29. Minamikawa, M., Hine, M., Russell, S., Huber, P., Duignan, P., and Lumsden, J. S. (2004) Fish Shellfish Immunol., 17, 463-476.

30. Uhlenbruck, G., Karduck, D., and Pearson, R. (1979) Comp. Biochem. Phys. B, Biochem. Mol. Biol., 63, 125-129.

31. Trip, M. R. (1966) J. Invertebr. Pathol., 8, 478-481.

32. Acton, R. T., Bennet, J. C., Evane, E. E., and Schrohenloher, R. E. (1969) J. Biol. Chem., 244, 4128-4145.

33. Matsubara, H., Nakamura-Tsuruta, S., Hirabayashi, J., Jimbo, M., Kamiya, H., Ogawa, T., and Muramoto, K. (2007) Biosci. Biotechnol. Biochem., 71, 513-519.

34. Gourdine, J. P., Markiv, A., and Smith-Ravin, J. (2007) Fish Shellfish Immunol., 23, 831-839.

35. Olafsen, J. A., Fletcher, T. C., and Grant, P. T. (1992) Dev. Comp. Immunol., 16, 123-138.

36. Yamaura, K., Takahashi, K. G., and Suzuki, T. (2008) Comp. Biochem. Physiol. B, Biochem. Mol. Biol., 149, 168175.

37. Bulgakov, A. A., Park, K. I., Choi, K. S., Lim, H. K., and Cho, M. (2004) Fish Shellfish Immunol., 16, 487-499.

38. Kim, Y. M., Park, K. I., Choi, K. S., Alvarez, R. A., Cummings, R. D., and Cho, M. (2006) J. Biol. Chem., 281, 26854-26864.

39. Kim, J. Y., Adhya, M., Cho, S. K., Choi, K. S., and Cho, M. (2008) Fish Shellfish Immunol., 25, 598-603.

40. Takahashi, K. G., Kuroda, T., and Muroga, K. (2008) Comp. Biochem. Physiol. B, Biochem. Mol. Biol., 150, 45-52.

41. Adhya, M., Choi, K. S., Yu, Y., and Cho, M. (2010) J. Fish Dis., 33, 889-899.

42. Dam, T. K., Sarkar, M., Ghosal, J., and Choudhury, A. (1992) Mol. Cell. Biochem., 117, 1-9.

43. Dam, T. K., Sarkar, M., Ghosal, J., and Choudhury, A. (1993) Biochem. Biophys. Res. Commun., 196, 422-429.

44. Jimbo, M., Usui, R., Sakai, R., Muramoto, K., and Kamiya, H. (2007) Comp. Biochem. Physiol. B, Biochem. Mol. Biol., 147, 164-171.

45. Watanabe, Y., Shiina, N., Shinozaki, F., Yokoyama, H., Kominami, J., Nakamura-Tsuruta, S., Hirabayashi, J., Sugahara, K., Kamiya, H., Matsubara, H., Ogawa, T., and Muramoto, K. (2008) Dev. Comp. Immunol., 32, 487-499.

46. Naganuma, T., Ogawa, T., Hirabayashi, J., Kasai, K., Kamiya, H., and Muramoto, K. (2006) Mol. Divers., 10, 607-618.

47. Park, J., and Kim, H. (1987) Korean Biochem. J., 20, 208214.

48. Fujii, Y., Dohmae, N., Takio, K., Kawsar, S. M., Matsumoto, R., Hasan, I., Koide, Y., Kanaly, R. A., Yasumitsu, H., Ogawa, Y., Sugawara, S., Hosono, M., Nitta, K., Hamako, J., Matsui, T., and Ozeki, Y. (2012) J. Biol. Chem., 287, 44772-44783.

49. Belogortseva, N. I., Molchanova, V. I., Kurika, A. V., Skobun, A. S., and Glazkova, V. E. (1998) Comp. Biochem. Physiol. C, Pharmacol. Toxicol. Endocrinol., 119, 45-50.

50. Chikalovets, I. V., Kondrashina, A. S., Chernikov, O. V., Molchanova, V. I., and Lukyanov, P. A. (2012) Khim. Prirod. Soedin., 6, 933-936.

51. Furtak, V. A., Kurika, A. V., Belogortseva, N. I., Chikalovets, I. V., and Kleshchenko, Yu. (1999) Byul. Eksp. Biol. Med., 128, 1039-1041.

52. Chikalovets, I. V., Chernikov, O. V., Shekhova, E. A., Molchanova, V. I., and Lukyanov, P. A. (2010) Biol. Morya, 36, 70-74.
53. Hardy, S. W., Fletcher, T. C., and Geris, L. M. (1976) Biochem. Soc. Trans., 4, 473-475.

54. Renwrantz, L., and Stahmer, A. (1983) J. Comp. Physiol. B, Biochem. Syst. Environ. Physiol., 149, 535-546.

55. Takagi, T., Nakamura, A., Deguchi, R., and Kyozuka, K. (1994) J. Biochem., 116, 598-605.

56. Pales Espinosa, E., Perrigault, M., and Allam, B. (2010) Comp. Biochem. Physiol. A, Mol. Integr. Physiol., 156, 495501.

57. Gorbushin, A. M., and Iakovleva, N. V. (2011) Fish Shellfish Immunol., 30, 434-438.

58. Mu, C., Song, X., Zhao, J., Wang, L., Qiu, L., Zhang, H., Zhou, Z., Wang, M., Song, L., and Wang, C. (2012) Fish Shellfish Immunol., 32, 716-723.

59. Chen, J., Xiao, S., and Yu, Z. (2011) Fish Shellfish Immunol., 30, 750-754.

60. Swalla, B. J., Cameron, C. B., Corley, L. S., and Garey, J. R. (2000) Syst. Biol., 49, 52-64.

61. Zeng, L., and Swalla, B. J. (2005) Can. J. Zool., 83, 24-33.

62. Arizza, V., Parrinello, N., and Schimmenti, S. (1991) Develop. Comp. Immunol., 15, 219-226.

63. Vasta, G. R., and Marchalonis, J. J. (1983) in Lectins: Biology, Biochemistry, Clinical Biochemistry, Vol. 3 (BogHanse, T. C., ed.), Walter De Gruyter, Berlin, pp. 461468.

64. Quesenberry, M. S., Ahmed, H., Elola, M. T., O'leary, N., and Vasta, G. R. (2003) Integr. Comp. Biol., 43, 323-330.

65. Green, P., Luty, A., Nair, S., Radford, J., and Raftos, D. (2006) Comp. Biochem. Physiol. B, Biochem. Mol. Biol., 144, 343-350.

66. Nair, S. V., Burandt, M., Hutchinson, A., Raison, R. L., and Raftos, D. A. (2001) Comp. Biochem. Physiol. C, Toxicol. Pharmacol., 129, 11-24.

67. Schluter, S. F., and Ey, P. L. (1989) Comp. Biochem. Physiol. B, Comp. Biochem., 93, 145-155.

68. Yokosawa, H., Sawada, H., Abe, Y., Numakunai, T., and Ishii, S. (1982) Biochem. Biophys. Res. Commun., 107, 451457.

69. Belogortseva, N., Molchanova, V., Glazunov, V., Evtushenko, E., and Lukyanov, P. (1998) Biochim. Biophys. Acta, 1380, 249-256.

70. Molchanova, V., Chicalovets, I., Li, W., Kobelev, S., Kozyrevskaya, S., Bogdanovich, R., Howard, E., and Belogortseva, N. (2005) Biochim. Biophys. Acta, 1723, 8290.

71. Suzuki, T., Takagi, T., Furukohri, T., Kawamura, K., and Nakauchi, M. (1990) J. Biol. Chem., 265, 1274-1281.

72. Ballarin, L., Tonello, C., Guidolin, L., and Sabbadin, A. (1999) Comp. Biochem. Physiol. B, Biochem. Mol. Biol., 123, 115-123.

73. Parrinello, N., and Arizza, V. (1988) Dev. Comp. Immunol., 12, 495-507.

74. Kelly, K. L., Cooper, E. L., and Raftos, D. A. (1992) Comp. Biochem. Physiol. B, 103, 749-753.

75. Parrinello, N., Arizza, V., Vazzana, M., Cammarata, M., Giaramita, F. T., Di Bella, M. L., Vizzini, A., and Parrinello, D. (2007) Invertebrate Surviv. J., 4, 55-64.

76. Epstein, J., Eichbaum, Q., Sheriff, S., and Ezekowitz, R. A. B. (1996) Curr. Opin. Immunol., 8, 29-35.

77. Kenjo, A., Takahashi, M., Matsushita, M., Endo, Y., Nakata, M., Mizuochi, T., and Fujita, T. (2001) J. Biol. Chem., 276, 19959-19965. 
78. Azumi, K., De Santis, R., De Tomaso, A., Rigoutsos, I., Yoshizaki, F., Pinto, M. R., Marino, R., Shida, K., Ikeda, M., Ikeda, M., Arai, M., Inoue, Y., Shimizu, T., Satoh, N., Rokhsar, D. S., Du Pasquier, L., Kasahara, M., Satake, M., and Nonaka, M. (2003) Immunogenetics, 55, 570-581.

79. Franchi, N., Schiavon, F., Carletto, M., Gasparini, F., Bertoloni, G., Tosatto, S. C., and Ballarin, L. (2011) Immunobiology, 216, 725-736.

80. Vasta, G. R., Hunt, J. C., Marchalonis, J. J., and Fish, W. W. (1986) J. Biol. Chem., 261, 9174-9181.

81. Vasta, G. R., Marchalonis, J. J., and Decker, J. M. (1986) J. Immunol., 137, 3216-3223.

82. Nakagawa, H., Yamaguchi, C., Sakai, H., Kanemaru, K., Hayashi, H., Araki, Y., Tomihara, Y., Shinohara, M., Ohura, K., and Kitagawa, H. (1999) J. Nat. Toxins, 8, 297-308.

83. Azumi, K., Ozeki, S., Yokosawa, H., and Ishii, S. (1991) Dev. Comp. Immunol., 15, 9-16.

84. Odintsova, N. A., Belogortseva, N. I., Ermak, A. V., Molchanova, V. I., and Lukyanov, P. A. (1999) Biochim. Biophys. Acta, 1448, 381-389.

85. Odintsova, N. A., Belogortseva, N. I., Khomenko, A. V., Chikalovets, I. V., and Lukyanov, P. A. (2001) Mol. Cell. Biochem., 221, 133-138.

86. Garte, S. J., and Russell, C. S. (1976) Biochim. Biophys. Acta, 439, 368-379.

87. Anderson, R. S. (1980) Biol. Bull., 159, 259-268.

88. Ozeki, Y., Tazawa, E., and Matsui, T. (1997) Comp. Biochem. Physiol. B, Biochem. Mol. Biol., 118, 1-6.

89. Mikheyskaya, L. V., Evtushenko, E. V., Ovodova, R. G., Belogortseva, N. I., and Ovodov, Yu. S. (1995) Carbohydr. Res., 275, 193-200.

90. Wang, J. H., Kong, J., Li, W., Molchanova, V., Chikalovets, I., Belogortseva, N., Luk'yanov, P., and Zheng, Y. T. (2006) Comp. Biochem. Physiol. C, Toxicol. Pharmacol., 142, 111-117.

91. Molchanova, V., Chikalovets, I., Chernikov, O., Belogortseva, N., Li, W., Wang, J. H., Yang, D-Y. O., Zheng, Y.-T., and Lukyanov, P. (2007) Comp. Biochem. Physiol. C, Toxicol. Pharmacol., 145, 184-193.

92. Kawsar, S. M. A., Takeuchi, T., Kasai, K., Fujii, Y., Matsumoto, R., Yasumitsu, H., and Ozeki, Y. (2009) Comp. Biochem. Physiol. B, Biochem. Mol. Biol., 152, 382389.

93. Kawsar, S. M. A., Mamun, S. M. A., Rahman, Md. S., Yasumitsu, H., and Ozeki, Y. (2010) World Acad. Sci. Eng. Technol., 37, 1110-1116.

94. Kawsar, S. M. A., Aftabuddin, S., Yasumitsu, H., and Ozeki, Y. (2010) Arch. Biol. Sci., 62, 1027-1034.

95. Ballarin, L., and Favero, M. (2010) Invertebrate Surviv. J., 7, 221-227.

96. Lukyanov, P. A., Chernikov, O. V., Kobelev, S. S., Chikalovets, I. V., Molchanova, V. I., and Li, W. (2007) Bioorg. Khim., 33, 172-181.

97. Miarons, P. B., and Fresno, M. (2000) J. Biol. Chem., 275, 29283-29289.

98. Dodd, R. Y., MacLennan, A. P., and Hawkins, D. C. (1968) Vox Sang., 15, 386-391.

99. Bretting, H., and Kabat, E. A. (1976) Biochemistry, 15, 3228-3236.

100. Pfeifer, K., Haasemann, M., Gamulin, V., Bretting, H., Fahrenholz, F., and Muller, W. E. (1993) Glycobiology, 3, 179-184.
101. Buck, F., Schulze, C., Breloer, M., Strupat, K., and Bretting, H. (1998) Comp. Biochem. Physiol. B, Biochem. Mol. Biol., 121, 153-160.

102. Miarons, P. B., and Fresno, M. (2000) J. Biol. Chem., 275, 29283-29289.

103. Gundacker, D., Leys, S. P., Schroder, H. C., Muller, I. M., and Muller, W. E. (2001) Glycobiology, 11, 21-29.

104. Pajic, I., Kljajic, Z., Dogovic, N., Sladic, D., Juranic, Z., and Gasic, M. J. (2002) Comp. Biochem. Physiol. C, Toxicol. Pharmacol., 132, 213-221.

105. Schroder, H. C., Ushijima, H., Krasko, A., Gamulin, V., Thakur, N. L., Diehl-Seifert, B., Muller, I. M., and Muller, W. E. (2003) J. Biol. Chem., 278, 32810-32817.

106. Muller, W. E., Zahn, R. K., Kurelec, B., Lucu, C., Muller, I., and Uhlenbruck, G. (1981) J. Bacteriol., 145, 548-558.

107. Kawagishi, H., Yamawaki, M., Isobe, S., Usui, T., Kimura, A., and Chiba, S. (1994) J. Biol. Chem., 269, $1375-1379$.

108. Atta, A. M., Barral-Netto, M., Peixinho, S., and SousaAtta, M. L. (1989) Braz. J. Med. Biol. Res., 22, 379-385.

109. Atta, A. M., Menezes, E. P., Peixinho, S., and Sousa-Atta, M. L. (1990) Braz. J. Med. Biol. Res., 23, 191-194.

110. Xiong, C., Li, W., Liu, H., Zhang, W., Dou, J., Bai, X., Du, Y., and Ma, X. (2006) Comp. Biochem. Physiol. C, Toxicol. Pharmacol., 143, 9-16.

111. Jin, Q., Li, W., Liu, J., Kong, L., Tong, C., Song, Y., Liu, C., Chernikov, O., Molchanova, V., Chicalovets, I., and Lukyanov, P. (2010) in Proc. of 2010 Int. Conf. of National Product and Traditional Medicine, Sci. and Tech. Dev. Press, China, pp. 372-376.

112. Boyd, W. C., Almodovar, L. R., and Boyd, L. G. (1966) Transfusion, 6, 82-83.

113. Kamiya, H., Shimomi, K., and Shimizu, Y. (1980) J. Nat. Prod., 43, 136-139.

114. Kawakubo, A., Makino, H., Ohnishi, J. I., Hirohara, H., and Hori, K. (1997) J. Appl. Phycol., 9, 331-338.

115. Benevides, N. M. B., Holanda, M. L., Melo, F. R., Freitas, A. L. P., and Sampaio, A. H. (1998) Bot. Mar., 41, 521-525.

116. Leite, Y. F., Silva, L. M., Amorim, R. C., Freire, E. A., Melo, D. M., Grangeiro, T. B., and Benevides, N. M. (2005) Biochim. Biophys. Acta, 1724, 137-145.

117. Nascimento, K. S., Nagano, C. S., Nunes, E. V., Rodrigues, R. F., Goersch, G. V., Cavada, B. S., Calvete, J. J., Saker-Sampaio, S., Farias, W. R., and Sampaio, A. H. (2006) Biochem. Cell Biol., 84, 49-54.

118. Hori, K., Miyazawa, K., and Ito, K. (1990) Hydrobiologia, 204/205, 561-566.

119. Ainouz, I. L., and Sampaio, A. H. (1991) Bot. Mar., 34, 211-214.

120. Oliveira, S. R. M., Nascimento, A. E., Lima, M. E. P., Leite, Y. F. M. M., and Benevides, N. M. B. (2002) Rev. Bras. Bot., 25, 397-403.

121. Lima, E. P., Carneiro, M. E., Nascimento, A. E., Grangeiro, T. B., Holanda, M. L., Amorim, R. C. N., and Benevides, N. M. B. (2005) J. Agric. Food Chem., 53, 6414-6419.

122. Shiomi, K., Yamanaka, H., and Kikuchi, T. (1981) Bull. Japan. Soc. Sci. Fish, 47, 1079-1084.

123. Sampaio, A. H., Rogers, D. J., Barwell, C. J., SakerSampaio, S., Nascimento, K. S., Nagano, C. S., and Farias, R. L. (2002) J. Appl. Phycol., 14, 489-495. 
124. Kamiya, H., Ogata, K., and Hori, K. (1982) Bot. Mar., 25, 537-540.

125. Melo, F. R., Benevides, N. M. B., Pereira, M. G., Holanda, M. L., Mendes, F. N. P., Oliveira, S. R. M., Freitas, A. L. P., and Silva, L. M. C. M. (2004) Rev. Bras. Bot., 27, 263-269.

126. Molchanova, V., Chernikov, O., Chikalovets, I., and Lukyanov, P. (2010) Bot. Mar., 53, 69-78.

127. Vasta, G. R., and Ahmed, H. (1996) Prog. Mol. Subcell. Biol., 17, 158-182.

128. Kamiya, H. (1995) Fish Pathol., 30, 129-139.

129. Tunkijjanukij, S., and Olafsen, J. A. (1998) Dev. Comp. Immunol., 22, 139-150.

130. Liao, W., Lin, J., Shieh, W., Jeng, W., and Huang, R. (2003) J. Ind. Microbiol. Biotechnol., 30, 433-439.

131. Holanda, M., Melo, V., Silva, L., Amorim, R., Pereira, M., and Benevides, N. (2005) Braz. J. Med. Biol. Res., 38, 1769-1773.

132. Adhya, M., Singha, B., and Chatter-jee, B. (2009) Fish Shellfish Immunol., 27, 1-8.

133. Chernikov, O., Chikalovets, I., Molchanova, V., and Lukyanov, P. (2007) Vestnik DVO RAN, 6, 31-35.

134. Yamanish, T., Yamamoto, Y., Hatakeyama, T., Yamaguchi, K., and Oda, T. (2007) J. Biochem., 142, 587-595.

135. Abreu, T. M., Silva, L. C. M., Vanderlei, E., de Melo, C., Pereira, V., and Benevides, N. B. (2012) Protein Pept. Lett., 19, 975-981.

136. Malagoli, D. (2010) Invertebrate Surviv. J., 7, 146-148.

137. Ashraf, M. T., and Khan, R. H. (2003) Med. Sci. Monit., 9, 265-269.

138. Engel, M., Bachmann, M., Schroder, H. C., Rinkevich, B., Kljajic, Z., Uhlenbruck, G., and Muller, W. E. (1992) Biochimie, 74, 527-537.

139. Dogovic, N., Sladic, D., Kljajic, Z., Poznanovic, S., and Gasic, M. J. (1996) Chem. Soc., 60, 83-88.

140. Pajica, I., Kljajicb, Z., Dogovicc, N., Sladica, D., Juranicd, Z., and Gasica, M. J. (2002) Comp. Biochem. Physiol., 132, 213-221.
141. Lima, H. C., Costa, F. H., Sampaio, A. H., Neves, S. A., Benevides, N. M., Teixeira, D. I., Rogers, D. J., and Freitas, A. P. (1998) J. Appl. Phycol., 10, 153-162.

142. Kawakubo, A., Makino, H., Ohnishi, J., Hirohara, H., and Hori, K. (1997) J. Appl. Phycol., 9, 331-338.

143. Li, Y., Zhang, X., Chen, G., Wei, D., and Chen, F. (2008) Curr. Med. Chem., 15, 1096-1104.

144. Huskens, D., and Schols, D. (2012) Mar. Drugs, 12, 14761497.

145. Mori, T., O’Keefe, B., Sowder, R., Bringans, S., Gardella, R., Berg, S., Cochran, P., Turpin, J., Buckheit, R., McMahon, J., and Boyd, M. (2005) J. Biol. Chem., 280, 9345-9353.

146. O'Keefe, B., Giomarelli, B., Barnard, D., Shenoy, S., Chan, P., McMahon, J., Palmer, K., Barnett, B., Meyerholz, D., Wohlford-Lenane, C., and McGray, P. (2010) J. Virol., 84, 2511-2521.

147. Meuleman, P., Albecka, A., Belouzard, S., Vercauteren, K., Verhoye, L., Wychowski, C., Leroux-Roels, G., Palmer, K., and Dubuisson, J. (2011) Antimicrob. Agents Chemother., 55, 5159-5167.

148. Ishag, H., Li, C., Huang, L., Sun, M., Wang, F., Ni, B., Malik, T., Chen, P., and Mao, X. (2013) Arch. Virol., 158, 349-358.

149. Kouokam, J. C., Huskens, D., Schols, D., Johannemann, A., Riedell, S. K., Walter, W., Walker, J. M., Matoba, N., O'Keefe, B. R., and Palmer, K. E. (2011) PLoS One, 6, e22635.

150. O'Keefe, B. R., Vojdani, F., Buffa, V., Shattock, R. J., Montefiori, D. C., Bakke, J., Mirsalis, J., d'Andrea, A. L., Hume, S. D., Bratcher, B., Saucedo, C. J., McMahon, J. B., Pogue, G. P., and Palmer, K. E. (2009) Proc. Natl. Acad. Sci. USA, 106, 6099-6104.

151. Sato, Y., Morimoto, K., Hirayama, M., and Hori, K. (2011) Biochem. Biophys. Res. Commun., 405, 291-296.

152. Sato, Y., Hirayama, M., Morimoto, K., Yamamoto, N., Okuyama, S., and Hori, K. (2011) J. Biol. Chem., 286, 19446-19458. 